\title{
Improved Inventory Management System for a Jute Mill - A Case Study.
}

\author{
Md Arafat Hossain ${ }^{1}$, Kawser Hossain ${ }^{2}$, Shubhra Kanti Das ${ }^{3}$, Joyanta Paul ${ }^{4}$ \\ ${ }^{[1,2,3,4]}$ Department of Mechanical Engineering, Khulna University of Engineering \&Technology (KUET), \\ Khulna-9203, BANGLADESH
}

\begin{abstract}
This project work has been carried out for investigating the existing Inventory Management system of the Eastern jute Mills Limited, Khulna, Bangladesh. Eastern Jute Mills Limited manufactures jute products such as hessian, sacks, and jute carpet backing clothes. It was founded in 1967 and is based in Khulna, Bangladesh. It also operates as a subsidiary of Bangladesh Jute Mills Corporation. For investigating the Inventory related data and information, the necessary data has been collected from this Jute Mill. By close look of the present inventory management system and discussing with the executive personals of the Eastern Jute Mills Limited, Khulna, A clear conception of the existing Inventory Management system has been gained. ABC analysis has been carried out for annual demand. Raw Jute purchasing procedure has been examined and storing procedure has been observed by close observation to find out the major drawback of the existing inventory management system. Finally it has been focused to suggest an improved Inventory Management system for the Eastern Jute Mills Limited, Khulna, Bangladesh.
\end{abstract}

Keywords: Inventory Management, Demand, Lead time, Holding cost, Depreciation, ABC Analysis

\section{Introduction}

In Operations Management, inventory refers to any scarce resource that remains idle in anticipation of satisfying a future demand for it. [1] An inventory is a stock or store of goods. [1] Inventory management is an important concern for the managers in all types of businesses. Effective inventory management is essential for realizing the full potential of any value chine. [2] Inventory primarily arises because of differences in the timing or rate of supply and demand and is used to balance these. Inventory may also occur due to economic batch sizes for an operation, WIP, product seasonality and investment for new product ranges. [3]

Holding inventory is often interpreted as carrying an asset but also means carrying risk in terms of obsolescence, deterioration and quality faults [4]. In financial terms inventory impacts the balance sheet, cash flow and profit and loss accounts. Operationally inventory affects production efficiencies and on-time delivery. In his book "The Goal" Goldratt [5] identifies inventory as a key component for measuring business performance in a manufacturing environment. Inventory represents an important decision variable at all stages of product manufacturing, distribution and sales. [6]

The objectives of the project work were:

\section{Objectives}

1) To study the present inventory management system of the Eastern Jute mills, Khulna.

2) To figure out the limitations and drawbacks associate with the existing inventory management system of the Eastern Jute mills, Khulna.

3) To suggest some methods to prosecute the inventory management system of the Eastern Jute mills, Khulna

\section{Steps Followed To Complete The Project Work}

1. At first, the rules and principle of the inventory management system was studied intensively to gain the proper managerial knowledge about inventory management.

2. Secondly, a close look on the inventory management system of Eastern Jute Mills, Khulna was given by collecting data of purchasing goods for the production, having discussion with the concerned personnel and visiting the Eastern Jute Mills of Khulna to observe how goods are kept.

3. Thirdly, the drawbacks associated with the inventory management system of Eastern Jute Mill of Khulna were figured out by means of case study.

4. Lastly, some suggestions were given to meet the anticipated demand and to eliminate the drawbacks and to maintain the inventory management system of Eastern Jute Mills of Khulna with more efficiently. 


\section{Data Collection And Calculation}

- Estimate the required items $=4$ days

- $\quad$ Advertisement $=7$ days

- Item verification $=7$ days

- Item preparing $=7$ days

- Tender receiving time $=10$ days

- Tender verification for comparative statements $=14$ days

- Get order $=4$ days

- Order preparing $=25$ days

- Inspection the ordering products $=5$ days

- $\quad$ Deliver the products $=5$ days

In total $=88$ days

So, Lead time $=88$ days

\section{Determination Of Inventory Related Cost}

8.1 Holding Cost: The holding cost includes handling, insurance, taxes, carrying cost of goods or raw materials.

- Bank interest on the money invested in inventory $=9 \%$

- Depreciation: Batching to batching $=0.50 \%$, Preparing to winding $=0.95 \%$, Beaming $=0.05 \%$, Weaving $=4 \%$, Finishing $=1 \%$, Jute to jute $=0.5 \%$

- $\quad$ Insurance $=0 \%$

- Expense of running mills $=14 \%$

So, Total holding cost $\mathrm{C}_{\mathrm{H}}=30 \%$

Shortage cost: This Cost arises when the Actual demand can't be met by the existing stock.

Lower ordering costs: If you buy a larger quantity of an item less frequently, the ordering costs are less than buying smaller quantities over and over again. (The costs of holding the item for a longer period of time, however, will be greater.) [7]

In Case of Eastern Jute Mills, Shortage cost is Totally Zero. This is because the actual demand is always met by the existing stock.

Ordering cost: This cost takes place by ordering from outside supplier or by producing the items internally.

- Cost of publicity and advertisement $=95000$ Taka

- $\quad$ Cost due to the telephone calls= 60000 Taka

- $\quad$ Postage and telegram $=5000$ Taka

So, Ordering cost, $\mathrm{C}_{\mathrm{R}}=160000$ Taka

\section{Equations Of Optional Replenishment System}

Here,

\begin{tabular}{|l|l|}
\hline Description & Equation \\
\hline Safety stock & $\mathrm{B}=\mathrm{zS} \mathrm{S}_{\mathrm{D}} \sqrt{t}+L$ \\
\hline Maximum inventory & $\mathrm{M}=\mathrm{D}\left(\begin{array}{l|}t \\
2\end{array}+L\right)+\mathrm{B}$ \\
\hline Reorder point & $\mathrm{R}=\mathrm{D}_{\mathrm{L}}+\mathrm{B}$ \\
\hline Holding cost & $\mathrm{C}_{\mathrm{H}}=\mathrm{c}_{\mathrm{H}}\left(\frac{M+B}{2}\right)$ \\
\hline Order size when $\mathrm{L}<\mathrm{t}$ & $\mathrm{Q}_{\mathrm{i}}=\mathrm{M}-\mathrm{Q}\left(\mathrm{T}_{\mathrm{i}}\right)$ \\
\hline Order size when $\mathrm{L}>\mathrm{t}$ & $\left.\mathrm{Q}_{\mathrm{i}}=\mathrm{M}-\left[\mathrm{Q}\left(\mathrm{T}_{\mathrm{i}}\right)+\mathrm{O}\left(\mathrm{T}_{\mathrm{i}}\right)\right]\right)$ \\
\hline
\end{tabular}

Table: 1 Necessary equations of the optional replenishment system

$M=$ Maximum inventory, $B=$ Safety stock, $R=$ Reorder point, $C_{H}=$ Cost of holding 1 unit per unit time, $C_{H}=$ Holding cost, $z=$ Number of standard deviation away from the mean, $S_{D}=$ Daily standard deviation, $D=$ Demand per day, $D_{L}=$ Lead time demand, $L=$ Lead time, $\mathrm{t}=$ Review period, $Q_{t}=$ Order size, $Q\left(T_{i}\right)=$ Inventory on hand at review time, $O\left(T_{i}\right)=$ Inventory ordered but not received. 
VII. Identifying Critical Inventory Items With Abc Analysis

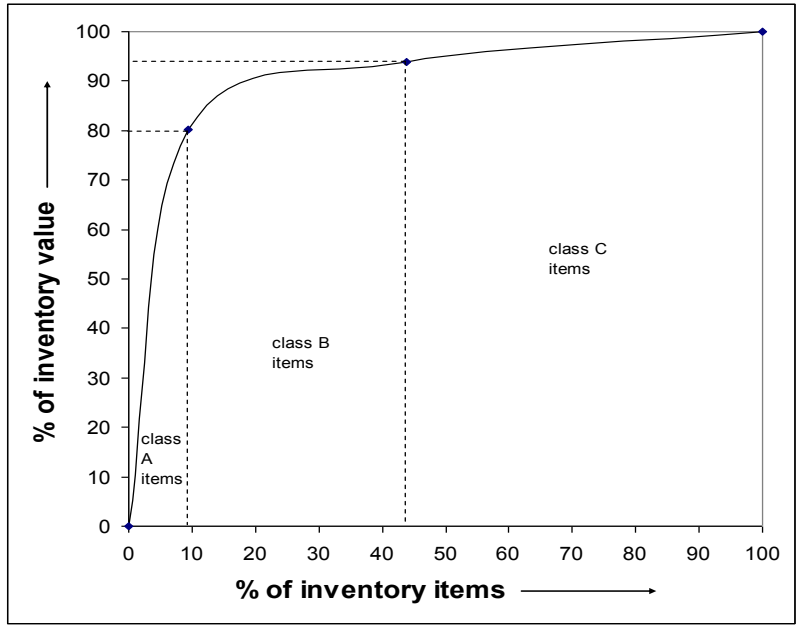

Figure: $1 \mathrm{ABC}$ analysis showing relationship between percentage of inventory items and percentage of inventory value

As figure shows, class A typically represents only about 20 percent of the items but account for 80 percent of the dollar usage. Class B items account for another 30 percent of the items but only 15 percent, of the dollar usage. Finally, 50 percent of the items fall in class C, representing a mere 5 percent of the dollar usage.

\begin{tabular}{|c|c|c|c|c|c|}
\hline \multirow[t]{2}{*}{ SL } & \multirow[t]{2}{*}{ Raw materials } & \multirow[t]{2}{*}{ Unit } & \multirow[t]{2}{*}{ Amounts } & Per unit price & Total price \\
\hline & & & & (Taka) & (taka) \\
\hline 1. & Raw Jute & Tons & 7260 & 43467 & 315570420 \\
\hline \multicolumn{5}{|c|}{ Total Class of $\mathrm{A}$ items $=$} & 315570420 \\
\hline 2. & Baling hoops & $\mathrm{Kg}$ & 44928 & 74 & 3324672 \\
\hline 3. & Paperboard tubes & Pieces & 1320 & 729 & 962280 \\
\hline 4. & Jute batching oils & Litter & 221748 & 46 & 10200408 \\
\hline \multicolumn{5}{|c|}{ Total Class of B items $=$} & 14487360 \\
\hline 5. & Baling pins & $\mathrm{Kg}$ & 2400 & 84 & 201600 \\
\hline 6. & Baling buckles & $\mathrm{Kg}$ & 4800 & 78 & 374400 \\
\hline 7. & Polythin Sheet & $\mathrm{Kg}$ & 630 & 143 & 90090 \\
\hline 8. & Emulsifier & $\mathrm{Kg}$ & 432 & 260 & 112320 \\
\hline 9. & Starch & $\mathrm{Kg}$ & 20364 & 40 & 814560 \\
\hline 10. & Dyes Chemicals & $\mathrm{Kg}$ & 90 & 493 & 44370 \\
\hline \multicolumn{5}{|c|}{ Total Class of $\mathrm{C}$ items $=$} & 1637340 \\
\hline
\end{tabular}

Table: $2 \mathrm{ABC}$ analysis for annual demand of Eastern Jute Mills.

Total number of items $=10$

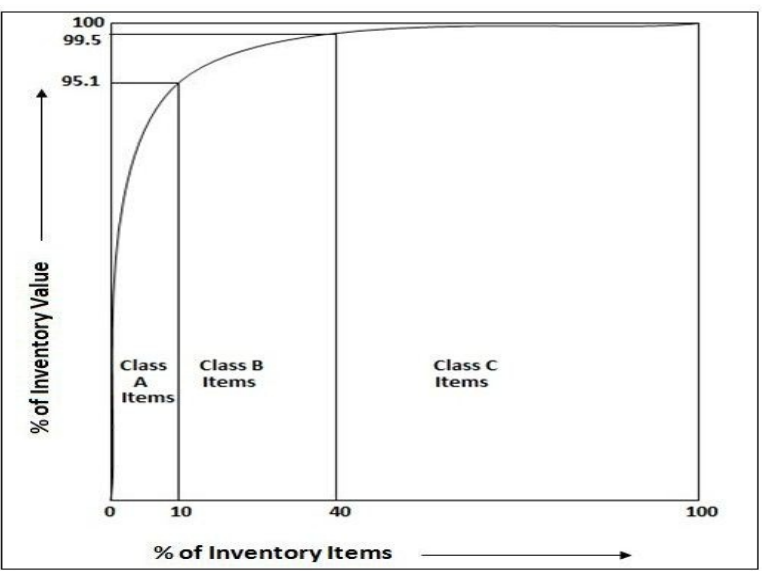

Figure:2 ABC analysis for the annual demand of the Eastern Jute Mills 
Total price of 10 items $=315570420+14487360+1637340=331695120$ Taka Now,

Total number of Class-A items $=1$ and percentage of Class-A items $=\frac{1}{10} \times 100=10 \%$

Total price of Class-A items $=315570420$ Taka

$\%$ of price of Class-A items $=\frac{315570420}{331695120} \times 100=95.1 \%$

Total number of Class-B items $=3$. Percentage of Class-B items $=\frac{3}{10} \times 100=30 \%$

Total price of Class-B items $=14487360$ Taka

$\%$ of price of Class-B items $=\frac{14487360}{331695120} \times 100=4.4 \%$

Total number of Class-C items $=6$. Percentage of Class-C items $=\frac{6}{10} \times 100=60 \%$

Total price of Class-C items $=1637340$ Taka

$\%$ of price of Class-C items $=\frac{1637340}{331695120} \times 100=0.50 \%$

\section{Sample Calculation For Item No-1 (Raw Jute) For 1 Year Review Period}

Unit price, $b=43467$ taka

Annual demand $=7260$ tons

Percentage of value invested in inventory, $\mathrm{f}=30 \%$

Service level $=85 \%$

So, $\mathrm{z}=1.0364$ (from normal distribution curve)

Daily Standard deviation, $\mathrm{S}_{\mathrm{D}}=9.45$

Lead time, $\mathrm{L}=88$ days

There is one holiday is a week in Eastern jute mills and generally there are 52 weeks in a year.

So, number of working days in a year in Eastern jute mills $=365-(1 \times 52)$ days $=313$ days

Review period, $\mathrm{t}=313$ days. Demand per day, $\mathrm{D}=\frac{7260}{313}=23.19$ tons. Safety stock, $\mathrm{B}=\mathrm{zS}_{\mathrm{D}} \sqrt{\frac{\mathrm{t}}{2}+L}=1.0364 \times$

$9.45 \times \sqrt{\frac{313}{2}+88}=153$. Maximum stock, $\mathrm{M}=\mathrm{D}\left(\frac{\mathrm{t}}{2}+L\right)+\mathrm{B}=23.19\left(\frac{313}{2}+88\right)+153=5823$

Reorder point, $\mathrm{R}=\left(\right.$ lead time demand, $\left.\mathrm{D}_{\mathrm{L}}\right)+\mathrm{B}=\frac{7260}{313} \times 88+153=2194$

So, holding cost, $\mathrm{C}_{\mathrm{H}}=\mathrm{c}_{\mathrm{H}}\left(\frac{M+\mathrm{B}}{2}\right)=\mathrm{b} \times \mathrm{f} \times\left(\frac{M+\mathrm{B}}{2}\right)==43467 \times 0.3 \times\left(\frac{5823+153}{2}\right)=38996419$ Taka

\begin{tabular}{|c|c|c|c|c|c|}
\hline \multirow[t]{2}{*}{$\overline{\mathrm{SL}}$} & \multirow[t]{2}{*}{ Raw materials } & \multirow[t]{2}{*}{ Unit } & Unit price & \multirow[t]{2}{*}{ Annual demand } & Holding Cost \\
\hline & & & (b) & & $\left(\mathrm{C}_{\mathrm{H}}\right)$ Taka \\
\hline 1 & Raw Jute & Tons & 43467 & 7260 & 38996419 \\
\hline 2 & Baling hoops & $\mathrm{Kg}$ & 74 & 44928 & 411877 \\
\hline 3 & Baling pins & $\mathrm{Kg}$ & 84 & 2400 & 24885 \\
\hline 4 & Baling buckles & $\mathrm{Kg}$ & 78 & 4800 & 46215 \\
\hline \multirow[t]{2}{*}{5} & Paper & \multirow[t]{2}{*}{ Pieces } & \multirow[t]{2}{*}{729} & \multirow[t]{2}{*}{1320} & \multirow[t]{2}{*}{119192} \\
\hline & board tubes & & & & \\
\hline 6 & Jute batching oils & Litter & 46 & 221748 & 1258808 \\
\hline 7 & Polythin Sheet & $\mathrm{Kg}$ & 143 & 630 & 11111 \\
\hline 8 & Emulsifier & $\mathrm{Kg}$ & 260 & 432 & 13845 \\
\hline 9 & Starch & $\mathrm{Kg}$ & 40 & 20364 & 100518 \\
\hline 10 & Dyes Chemicals & $\mathrm{Kg}$ & 493 & 90 & 5472 \\
\hline & & Holdin & & & 40988342 \\
\hline
\end{tabular}

Table: 3 Holding cost for raw materials for 1 year review period.

For 1 year review period has been taken under consideration, Total holding cost $=40988342$ Taka.

So, total incremental cost, TIC $=\mathrm{C}_{\mathrm{H}}+\mathrm{C}_{\mathrm{R}}=(40988342+160000) \mathrm{Taka}=41148342$ Taka

\section{Result:}

$\mathrm{ABC}$ analysis is obtained for the annual demand. In case of the annual demand, Class- $\mathrm{A}$ item is the raw jute which covers 10 percent of total raw materials and holds about 95 percent of total value. Class- $\mathrm{B}$ holds the 30 percent of total items and covers around the 3.5 to 4.5 percent of total value and Class- C holds 60 
percent of total items and covers around the 0.5 percent of total value. The total incremental cost of the 1 year review period is 41148342 Taka. This incremental cost is the summation of the entire three units and it has been calculated based on the annual demand of the Eastern Jute Mills.

\section{Suggestion}

Here are some suggestions to improve the existing inventory management system of the eastern Jute Mills.

1. Especially Raw Jute (Class- A item) should be put under extreme high control because only the Raw Jute holds around 95 percent of inventory value. If the wastage of the raw jute can be minimized, it will be possible to minimize the total holding cost.

2. It is necessary to provide the more space to store the raw jute. If more spaces are provided and are not stored more compactly, the wastage will be minimized. The raw jute should be process before storage. It can minimize the total wastage and can minimize the total holding cost.

3. By proper maintenance and replacement of parts, these machines can perform as close to a new one. It is necessary to install the new or automatic machineries to decrease the loose of raw materials.

4. In today's business environment, even small and mid-sized businesses have come to rely on computerized inventory management systems. [10] So the inventory management of the mill should be relied on the computerized inventory management system. A computerized inventory management system is more accurate and reliable.

But if the inventory management system is estimated by 2 review period (July to December and January to June) in a year, it will be easier process and can be made many important decisions quickly.

\section{Discussion}

For studying the entire inventory management system of the Eastern Jute Mills, the inventory related data has been collected from the Hessian unit, Sacking unit and $\mathrm{CBC}$ unit. Each unit has some individual needs and produces the individual products. The overall requirements of the annual demand of the Eastern Jute Mills have also been collected. The motive of this work is to adopt a suitable inventory management system which will serve as a model. From the presented data, total inventory costs for 1 year review have been figured out.

\section{Conclusion}

The Depreciation and wastage is high in Eastern Jute Mills which leads to a greater holding costs and finally greater incremental cost. By close observation, it is seen that the raw jute is under loose control that leads the greater depreciation and wastage of raw jute. There are spaces to stock the raw jute. But the spaces are not sufficient. By close observation, it is seen that the Raw Jute is stored in more compactly that can leads to more wastage. Normally huge amount of jute is bought at a time because it is available in June to September. Technology used in jute manufacturing sector did not change much. Most of the machines in jute mills are old and have passed the usual functional period. Due to the use of extreme old machine, the operation can't be performed smoothly and the materials are being loosen at a considerable rate. The expense of running mill is about the 14 percent which also added with the holding cost. The old machineries take huge amount of power but can't provide sufficient performance. Because of this reason the expense of running mill is high. Eastern Jute Mills estimates its Inventory management system for every 1 year (July to June). It is more complex to estimate the total inventory at a time.

\section{References}

[1] Dervitsiotis, Kostas N, “Operation Management” McGraw-Hill Book Company, United States of America, 1981.

[2] Ritzman, Larry P, Krajewski, Lee J, “Operation Management” Seven Edition, India, 2007.

[3] Geoff Relph, FIOM, Inventory Matters Limited, Witek Brzeski, IBM Business Consulting Services, Gail Bradbear, MIOM, IBM Industrial Practice. "The first steps to inventory management" (control December 2002/2003).

[4]. Zetie, S, "Stockholding: The Real Cost". BPICS Control April/May, 1990.

[5]. Goldratt, E, "The Goal", (2nd Edition). Gower Publishing, 1993.

[6] Temeng, V. A, Eshun, P. A, Essey, P. R. K, "Application of Inventory Management Principles to Explosive Products Manufacturing and Supply - A Case Study.” International Research Journal of Finance and Economics, 2010

[7] Muller, M, "Essentials of Inventory Management" United states of America, 2003. 